\title{
Iran's Use of Afghan Shiite Migrants as Proxies: The Case of Liwa Fatemiyoun
}

\author{
İbrahim Karataş*
}

\begin{abstract}
This study analyzes how migrants are militarized through analyzing an Iranian proxy, namely Liwa Fatemiyoun, as a case study. Liwa Fatemiyoun is a proxy group formed from migrants of the Shiite ethnic group of Afghan Hazaras by Iran. Shiite Hazaras immigrated to Iran due to ongoing civil wars in Afghanistan to find a safe haven. Numbering more than two million and crossing the borders illegally, Hazaras were recruited by the Iranian army either voluntarily or for a certain amount of money or by force. They were sent to Syria to protect holy shrines, but most of them found themselves in fronts. By analyzing the proxy group's formation, this study concludes that Iranian regime guards (IRGC) mostly conscript Afghan migrants and refugees to Liwa Fatemiyoun forcibly thereby exploiting their vulnerability and human rights. Besides, by referring to past experiences, the study asserts that Iran may also move the proxy group to Afghanistan if necessary after US troops' withdrawal. This study mainly wielded news, including those in Persian and institutional reports, and made interviews for its analysis. By examining Liwa Fatemiyoun, the study is expected to contribute to ethnoreligious migration literature from a security perspective.
\end{abstract}

Keywords: Liwa Fatemiyoun, Proxy Groups, Iran, Afghanistan, Migration.

* Dr., Visiting Scholar, Istinye Universiy, Institute of Social Sciences, Department of Political Science and International Relations, ibratas@gmail.com, ORCID: 0000-0002$2125-1840$ 


\title{
İran'ın Şii Afgan Göçmenleri Militan Olarak Kullanması: Liva Fatımiyun Örneği
}

\author{
İbrahim Karataş*
}

\section{Öz}

Bu çalışma, İran'a mülteci olarak veya kaçak yollarla gelen Şii Afganların İran tarafından nasıl vekil gruplara dönüştürüldüğünü analiz etmektedir. Bu amaç doğrultusunda Liva Fatımiyun örgütü detaylı olarak incelenmiştir. Liva Fatımiyun örgütü, Afgan Hazaralarından oluşturulan bir vekil örgüttür. Şii Hazaralar yıllardan beri devam eden iç savaştan dolayı Afganistan'ı terk edip İran'a yasal veya kaçak yollarla geçmek durumunda kalmışlardır. Herhangi bir sosyal hakları olmayan ve eğitim sistemine nadiren ulaşabilen mülteciler İran Devrim Muhafızları tarafından zorla, gönüllü veya para karşıllığı Liva Fatımiyun örgütüne alınmışlardır. Suriye'de kutsal türbeleri korumak için gönderilen militanlar kendilerini çoğunlukla ileri cephelerde bulmuşlardır. İran'a sağ dönen militanlara oturum gibi çeşitli haklar verilirken, ölenlerin ailelerine vatandaşlık verilmiştir. İran Devrim muhafızlarının kontrolünde olan örgüt bilhassa Suriye'de rejimin yanında aktif olarak savaşmıştır. Çalışmamız yaptığı analiz sonucunda Devrim Muhafızlarının Afganistan'daki savaştan kaçan göçmen ve mültecileri gerek ikna, gerek para gerekse de zorla Liva Fatımiyun'a dahil ederek onların mağduriyetlerini kullandığını iddia etmektedir. Ayrıca, Suriye'de belli bir süre çatı̧̧manın bedeli olarak İran'da oturum alan militanların Afganistan'a dönmeleri halinde İran'ın kontrolü altında çatı̧̧ma ihtimallerinin olduğunu öne sürmektedir. Nitekim İran Dışişleri Bakanı Cevat Zarif Liva Fatımiyun üyelerinin Afganistan'a dönmeleri gerektiğini beyan etmiştir. Makale için literatür taraması yapılmasının yanısıra, bazı Afganlarla röportajlar yapılmış ve Farsça haber kaynaklarından istifade edilmiştir.

Anahtar Kelimeler: Liva Fatımiyun, Vekil Gruplar, İran, Afganistan, Göç.

* $\quad$ Dr., Misafir Öğretim Üyesi, İstinye Üniversitesi, Sosyal Bilimler Enstitüsü, Siyaset Bilimi ve Uluslararası İlişkiler Bölümü, ibratas@gmail.com, ORCID: 0000-00022125-1840 


\section{Introduction}

Great powers have always used proxies (or surrogates) throughout history. Yet, their numbers increased with nuclear weapons' invention since superpowers, namely the United States and the Soviet Union, avoided a confrontation during the Cold War as casualties and devastation would be pretty high. With the beginning of the 21 st century, the US, Russia, China, and regional powers like Iran and Saudi Arabia in the Middle East began to use surrogates to realize their goals by minimizing their casualties and costs. Among principals utilizing surrogate groups, Iran can be regarded as the champion since it has more proxies than any other country. If the number of primary and affiliated proxy groups is counted, Iran might have more than one hundred militant armed organizations spreading all over the Middle East. Iran has become a regional power and felt its influence in countries, particularly those with a Shiite majority or minority such as Iraq, Lebanon, Syria, and Yemen. However, while the Iranian regime exported its ideology and increased its presence in mentioned countries, it also undermined the domestic stability. It is not a coincidence that countries that Iran intervened via proxy groups are failed states. Further to lack of authority, mentioned countries have become nests of terrorist groups. Failure of states cannot be attributed only to Iran, but its contribution to anarchy in the region is conspicuous.

This study analyzes Liwa Fatemiyoun, a proxy of Iran, which was formed from the Afghan Shiites of the Hazara ethnic group. Iran has been wielding Afghans since the revolution of 1979. It militarized them against the Soviet invasion in Afghanistan, against Sunni groups during the Afghan civil war and included them in IRGC ranks during the Iran-Iraq War. When the Syrian civil war erupted in 2011, IRGC sent some Afghan-origin fighters to Syria and founded Liwa Fatemiyoun in 2014. Liwa Fatemiyoun has to be analyzed because Iranian Republican Guards chose their members among two million illegal Afghan migrants and one million refugees. In other words, it seems that it exploited migrants for its regional ends, which require violence and end up with the death of militants. Iran either forcibly sent migrants to fronts by blackmailing them with deportation or offering them fundamental rights, which it has to give as per international law and moral values, or used Shiite creed to convince them. Also, this study asserts that the Afghan fighters Iran trained and deployed in Syria may be used in 
Afghanistan in case of a new civil or sectarian war in the country after US troops' withdrawal. Afghan interviewees denied this view, arguing that Iran already uses Sunni groups for influence. While their arguments are correct, it does not mean that Liwa Fatemiyoun will not be sent to Afghanistan as Iranian officials have recently called their return home. The group is under Iranian control. Thus a likely usage may not be out of the question.

This research aims to analyze how Iran changes the natures of proxy groups, proxy wars, migrants and migration. It also tries to unveil ethnoreligious relations' misuse by analyzing Iran's relations with Shiite Afghans and their armament by the Iranian regime. While analyzing Liwa Fatemiyoun, the study suggests its hypotheses and extracts new theoretical findings, which are laid down mainly in the last paragraph of sections. Methodologically, both quantitative and qualitative researches were used. Besides academic literature, Iranian media was searched, and some Afghan academicians were interviewed.

\section{Proxies}

Before going into detail, it should be noted that this study explains proxies with proxy wars to clarify the nature of the former. With the simplest definition, proxy groups are local forces with local grievances that are amplified by foreign sponsorship. According to Mumford (2013 p. 40), "Proxy wars are the indirect engagement in a conflict by third parties wishing to influence its strategic outcome". Karl Deutsch defines the term as an international conflict fought in a third country by two foreign powers that disguise itself as an internal issue and uses the hosting country's human power and resources for their interests (Deutsch, 1964, p. 102). Thus, warring parties support combatants rather than conducting a direct war. However, sometimes the principal might be a combatant while the other fights via a proxy, e.g., the case of Saudi Arabia vs. Iran in Yemen. Some leaders have defined the term as well. For example, US President Eisenhower called it 'the cheapest insurance the world' world'.

In contrast, Pakistani leader Ziya ul-Haq defined it as 'necessary to "keep the boiling' in existing conflict zones' (Mumford, 2013, p. 40). There are great actors and smaller ones in a proxy environment that are used as a proxy for common interests and objectives (Fox, 2019, p. 3). Actors can 
be states or non-states, and relations are hierarchical. Fox suggests two models of proxy warfare; the exploitative and the transactional. In the exploitative model, the proxy is dependent on the principal like a parasite. The proxy can not fulfill its goals without the principal's support. When the principal's ends are achieved, there will be no need for the proxy. US support to SDF, formed by Kurdish and Arab militants in Syria, is an example of the exploitative model (Fox, 2019, p. 9). However, such dependency is not the case in the transactional model. In this model, services and goods are exchanged, and the proxy does not have to subjugate to the principal. In other words, two independent big and small powers benefit from each other for mutual benefits and to defeat a common adversary (Fox, 2019, p. 3). Whatever the model is, great powers wield proxies to maximize and protect their interests and minimize their risks by not confronting its powerful adversary. While the proxy suffers more than the principal in such power relations, it still engages in it as it is not possible to realize its goals without training and military and financial help from the principal.

Also, a proxy war requires no direct intervention of a superpower. For instance, according to Bar-Siman-Tov (1984), Vietnam and Korean Wars were proxies as; 1) they were conducted on territories of smaller states while territories of big states/principals (China, America, and Russia) were war-free; 2) small state's resources and soils were used for ends of superpowers, and 3) superpowers and small powers had compatible goals. However, this view may not be true, at least for the US, because it fought on another soil, namely Vietnam, while China and Russia were not officially there. US army combatted with 500.000 soldiers and had 56.000 casualties during the Vietnam War. Therefore, war may not be called proxy because it took place in the adversary's territories. If Bar-Siman Tov's view is correct, all wars should be regarded as proxy wars then. Regarding why superpowers prefer fighting via proxies, first, conventional wars are more expensive, thus economically and politically, it is not worth spending billions and causing the death of thousands of soldiers, which may shake the warring country and government even if the war is won (Worcester, 2014). Whereas using a proxy is the cheapest option since proxy's militants/ soldiers will die on behalf of the benefactor, and a superpower will use less military and financial assets. 
However, proxy wars are more malicious than being beneficial. First, Krieg (2016) argues that superpowers may lose control and oversight over the proxy as it has fewer means to steer the surrogate. Since it is the proxy that combats, it has complete discretion on the course of the war, which can mislead or misinform the principal. Second, weapons, money, and other commodities provided to proxies might be misused, sold, or transferred to other groups. Third, when a proxy gets support from a benefactor, it acts fiercely and escalates violence. Such behaviors create more risks for both proxy and benefactor. Fourth, utilizing proxies might be dirty and immoral. When proxies commit crimes with the help of superpowers, e.g., killing civilians, legally the latter may be innocent, but morally it might be guilty as it indirectly contributed to wrongdoings. For example, Saudi Arabia and the UAE fought with US support in Yemen, and they did not discriminate between militants and civilians. Hence, the US is also supposed to be indirectly the perpetrator of killing innocent people. As Pfaff and Granfield (2018) correctly state, "Proxies may provide the United States an ability to offload some of its military costs and responsibilities, but they can not absolve the nation of its moral responsibilities". Therefore, proxy wars might be messier and costly than expected (Byman, 2018).

While proxy wars are considered as the general character of the $21 \mathrm{st}$ century, it is not a new phenomenon (Fox, 2019). This kind of war was fought even between Byzantines and Sassanids. Throughout history, empires benefited from proxies against their adversaries due to such warfare's cheap and low-risk aspects. Proxy wars sound rational to states, particularly when they do not incur direct threats and when their interests are significant but still sacrificial. For instance, while the British Empire directly fought with the Ottomans during the First World War, it supported the Greeks against Turks after the war. Since the British were safe without any significant enemy, it was not rational to fight Turks in Asia Minor as it would not get considerable gains. Instead, it preferred its ally, Greece, to conquer Turkish territories.

On the other hand, with the production of nuclear weapons during the Second World War by the US, followed by the Soviet Union, the UK, France, and China, superpowers avoided fighting each other due to the massive destruction capacity of atomic bombs. Waging a cold war instead of a hot war was rational since no winner would be in a nuclear 
war. Therefore, US-led Western bloc and Soviet bloc frazzled each other through their proxies on other states' territories. Besides, since superpowers can no longer find vassal states of the Cold War in the $21^{\text {st }}$ century, they use Private Military Companies (PMCs) instead. Worcester (2014) says that Putin approved the recruitment of PMCs in 2011, and since then, Russian mercenaries fighting in countries like Syria, Libya, and Ukraine under the control of the Ministry of Defense. On the other hand, the United States has a long history of utilizing mercenaries in Afghanistan, Iraq, Syria, and other countries. It is estimated that $57 \%$ of military personnel in Iraq between 2003 and 2007 were PMC operatives, to which the US paid \$6-10 billion, while there were 200.000 mercenaries in Afghanistan in the same period (Mumford, 2013 p. 43). However, when Obama became the President, the US policy for wars changed. US army withdrew most of its troops and began to fight through PMCs or local groups. With experiences taken from Afghan and Iraqi invasions, the Obama administration decided to lessen war costs and troops. Called 'Obama Doctrine' and defined with terms like 'leading from behind', 'directly non-intervention' and 'no boots on the grounds', President Obama also aimed to change the negative image of the US and decrease anti-Americanism (Ekşi, 2017, p. 111).

\section{Iran and Proxies}

The Iranian regime is blamed for being behind clandestine wars. When Israel invaded Lebanon in 1982, Iran sent the Iranian Revolutionary Guard Corps (IRGC) to Beqaa Walley and trained Shiite militias. These militias later formed Hezbollah, which is the most influential group in Lebanon both politically and militarily. After seeing Hezbollah's effectiveness, IRGC established its paramilitary organization called Quds Force-Sepah-E Quds (IRGC-QF), which consists of 15.000 soldiers and controls a large number of militants numbered between 130.000 and 180.000 (Jones, 2019, p. 4). IRGC-QF currently supports Hezbollah in Lebanon, Houthis in Yemen, Hashd Al-Sha'abi in Iraq (including Kata'ib Hezbollah, Badr Organization and Asaib Ahl al-Haq), Liwa Fatemiyoun in Afghanistan, Hamas in Palestine (Sunni), Liwa Zainabiyoun in Pakistan, Rasulallah Corps in Arabian Peninsula, Levant Corps in Syria, Lebanon and Jordan, Ramazan Corps in Iraq, and Ansar Corps in Afghanistan (Uskowi, 2019, p. 158). 
There are also sub-proxies operating under these groups. For example, there are more than twenty Iranian proxies only in Syria (Washington Institute, 2018). It is estimated that Iran spent around $\$ 15$ billion on these proxies.

Overall, Iran has armed proxy groups in many Middle Eastern countries. Throughout its proxies, Iran has hegemonic control over Iraq, Lebanon, and Syria and threatens other countries. Nevertheless, the fact that it was not Iran that initiated wars in mentioned countries should be emphasized. Iran just got benefited the lack of authority through the Shiite population and its proxies to control the mentioned countries. On some occasions, e.g., Iraq, it acted like an opportunist waiting for its turn. When Americans left Iraq, Iranians entered and did not leave the country. Also, it should be noted that Iran uses Shia ideology subtly to collect militants and send them to fronts. It quickly finds Shiite youth that will serve the Iranian regime by using ideology. Thanks to the proxies, Iran with a small GDP, which is insufficient to look after its citizens, has become the most influential country in the region.

There are several reasons why Iran resorts to creating proxies. First, the Iranian regime has been striving to export Shiite ideology since Khomeini took power in 1979. It spreads Shia theology via clerics and proxies in other countries. Second, the regime protects Shia minorities of other countries through proxies and uses them to maintain its influence. For instance, it would not have a say in Lebanese politics without Hezbollah. Third, proxies are used against hostile countries like Saudi Arabia, Bahrain, and Israel. While Iran has no confrontation with rival countries, its proxies fight, create chaos and undermine their politics. Finally, Al-Dassouky et al (2019) argue that reliance on militias is a sign of hardliners' growing influence, particularly IRGC, in Iran's foreign policy. That argument might be correct because Qasem Soleimani got its reputation and dominance in regional politics by leading Iran's proxies. Also, security officials are always advantageous against politicians since they can honor their countries with victories. Considering that Iran's proxy policy is successful, it will not be wrong to claim that IRGC's proxy policy increases military elites' impact in Iran.

Based on these facts, theoretically, I argue that when a proxy is fighting for religion, the principal's cost is less and affordable. As shown below, while 
Iran as a principal pays a small amount of money to militants and some social rights in Iran like residence permit, it convinces proxies mainly with non-payable spiritual awards like heaven. In other words, militants are expected to sacrifice their lives for their religious cause and benefit after death. In addition, there are no reciprocal benefits between principal and proxy in Iran's case as the principal is the sole beneficiary. Therefore, an Iranian proxy is not precisely a proxy or customer but a continuously dependent religious or ethnic group. In the same vein, proxies are exploited and forced to fight for the principal, meaning no agent's voluntariness against the principal. If militants are allowed, they will not fight for Iran.

\section{Liwa Fatemiyoun}

Liwa Fatemiyoun is one of Iran's most extensive proxies and the second biggest one operating in Syria after Hezbollah (of Lebanon). Liwa means 'brigade' in Arabic and Fatemiyoun refers to Prophet Muhammad's daughter 'Fatima'. As stated above, Iran gathers Shiite militants worldwide but particularly from Iraq, Afghanistan, Pakistan, Yemen, and Lebanon. Liwa Fatemiyoun is the contingent formed by IRGC from Shiite Afghans. Almost all members belong to the Persian-speaking Hazara ethnic group constituting $15-20 \%$ of the Afghan population (Therme, 2017, p. 511). The roots of Shiite armed formations go back to the Soviet invasion of Afghanistan in 1979. Iran helped Hazaras to create the Army of Muhammad against the Soviets. IRGC also gathered some Afghan militants under the name Abu Dhar Brigade and sent them to fronts to fight against the Saddam Hussein regime during the Iran-Iraq War (Al-Dassouky et al., 2019). It is estimated that some 3.000 Afghan militants were killed during the IranIraq War (Middle East Eye, 2018). It should be noticed that while these Afghans were fighting against the Hussain regime of Iraq, other Afghan groups were countering the Soviet Union. Therefore, Afghan Shiites were under the command of Iran while their countries were under occupation. However, when the Taliban controlled Afghanistan before the US invasion, Hazaras suffered from Taliban's persecution, thereby Iran helped Afghan Shiites to fight against Taliban militants, whom it saw as proxies of Pakistan and Saudi Arabia. When the US invaded Afghanistan in 2001, Iran ordered its Afghan proxies to side with the American army against Taliban. Yet, 
when George W. Bush defined Iran as a member of the Axis of Evil, Iran approached the Taliban.

As can be seen, Iran militarized the Shiite minority of Afghanistan from 1980 onwards, literally when the Iranian revolution was accomplished. While the enemy of Hazaras was shared with other Afghan groups in the 1980s, namely Soviets, they either did not ally with Sunni groups or the latter did not accept to cooperate with them. On the other hand, when the enemy was the US in 2001, they allied with the invader against the Sunni Taliban group. Besides Iran's Shiite expansionism, Sunni groups' brutality against the Shiite minority also legitimized Iran's involvement in the Afghan civil war. For instance, the Taliban killed more than 300 Shiites in Bamian province in 2001 (Mashal and Faizi, 2017). Also, ISIS also continuously killed Shiite Hazaras. Whether for defending people adhering to Shia Islam or expansionist goals, the Iranian regime could benefit from Shiite Hazara reservoir to recruit new militants that would combat inside and outside Afghanistan under the auspices and order of IRGC's Quds Force. Therefore, before Liwa Fatemyioun, Afghan militants were already mobile and fighting for more than three decades for Iran.

It is estimated that there were Afghan fighters in almost every conflict in which Iran got involved. However, the Fatemiyoun Brigades surfaced when the Syrian people revolted against Bashar Assad. Their arrival to Syria was first detected in 2012 when the Free Syrian Army captured some Afghan militants. It was later revealed that they were fighting alongside Iraqi Shiite militants in Liwa Abu Fadl al-Abbas (LAFA). Those fighters combatting in Syria confessed to the Western media and Human Rights Watch (HRW) that they were there to defend Shiite shrines near Damascus from ISIS (Sahraei, 2016; HRW, 2016). However, they also said that they were forced to fight in places like Aleppo, Homs, and Palmyra though they were inefficient in fighting in fronts. It is also known that they were on the front in Idlib together with Syrian regime forces in January and February 2020.

Regarding the brigade's formation, they have been named as Liwa Fatemiyoun since 2014. A new division was necessary because their numbers had risen to 14.0000 at that time as per some sources. On the other hand, from their first dispatch to Syria until 2017, the total turnover of Fatemiyoun members was around 50.000 (Jamal, 2019, p. 7). In other 
words, so many Afghan fighters fought at least once in Syria. Considering that three more years have passed over 2017, that number might be 60.000 as of 2020 . Besides, 2.000 of them were killed and 8000 wounded in the same period (Middle East Eye, 2018). Overall, Liwa Fatemiyoun with tens of thousands of militias, has learned how to fight over time and is ready or can be readied for likely confrontations.

Theoretically, I contend that unlike other principal-proxy relations, the proxy is mobile in the case of Iran-Liwa Fatemiyoun relationship. When Iran needs militants, it forms a proxy group with a different name if required and sends it to whichever country the Iranian regime wants. Therefore, Iran's militant groups, including Liwa Fatemiyoun, look like a PMC rather than a proxy group.

\section{Afghan Migrants as the Militias of Liwa Fatemiyoun}

What makes Liwa Fatemiyoun distinctive (but not exclusive) is that (1) Iran chooses fighters from undocumented Afghan migrants, and (2) it may pose a threat to Afghanistan. In other words, as this study argues, Iran is exploiting the vulnerability of migrants for its ends and may use them to cause conflicts in the home country, Afghanistan. According to Smyth (2014), Liwa Fatemiyoun has three primary sources: it picks up militants. First, some of them were already residing near the Sayyida Zainab shrine in Syria. This group immigrated to Syria due to the Taliban's hostility against them long before the Syrian civil war. When the war broke out, they were targeted by hostile groups and eventually joined regime forces. The second source is Afghan refugees living in countries other than Syria and Iran, such as Europe and Australia. Shay (2019:3) argues that IRGC and Iranian intelligence service brought fighters among tens of thousands of Afghans entering Europe in the last decades. However, the third and the biggest source is Afghan refugees residing in Iran, who escaped from continuous conflicts and wars in Afghanistan. As can be seen, all these three sources are refugee communities spreading all over the world but Iran.

War-torn Afghanistan hit Shiite Hazaras in many aspects. In addition to foreign invasion, they were also victims of sectarian conflicts. From the beginning of the Soviet invasion onwards, they left their homes for more secure places. Poverty was also a reason that forced them to migrate. As 
usual, their first choice was Iran since this country was being ruled by Shiite theology. There are three million Afghans in Iran, but only one million of them have refugee status. Since most of them are illegally living in Iran, they have no right to study, buy a home, travel to another place, and even possess a mobile number. They have to hide in order not to be captured by the police and deported back to Afghanistan. Besides deportation, they had a new reason for escaping from the Iranian police; being sent to Syria for fighting. In addition to migrant recruits, IRGC and its agents also conducted direct recruitment from Afghanistan. It used Shiite scholars to contact people and convince them to fight in Syria (Alijani \& Hilliar, 2014). While giving religious courses in their compounds, clerics also praised martyrdom for religion. Moreover, there were also Afghan companies in pilgrimage services, which helped recruits go to Iran and finally head to Syria (Jamal, 2019, p. 7). Such rumors can be assumed as correct because Afghan media reported several times the detentions of recruiters. Besides, the Afghan government warned the Iranian regime many times to stop such activities.

Afghan migrants are indeed a lucrative source for IRGC's Quds Force to be used as members of their proxies spreading all over the Middle East. Interviews made with ex-fighters and concerning news and reports reveal how they found themselves in Liwa Fatemiyoun and other groups' ranks. One thing that Iranian security officials exploit is poverty. Shiites of Afghanistan live on less than $\$ 25$ a month, thus they immigrate illegally to Iran to make money to help their families. They win more than $\$ 200$ if they work as workers in the construction business in Iran. However, there is always the risk of being caught by Iranian authorities and deported back to their home. IRGC is aware of migrants' poor circumstances and exploits them for its regional goals. For example, Mr. Amin, an illegal Afghan immigrant, was proposed $\$ 800$ salary and a 10 -year residence permit to go to Syria to protect the Sayyida Zainab shrine in Damascus (Latifi, 2017). As per various sources, their salaries change from $\$ 500$ to $\$ 1000$, excluding rewards and premiums. For instance, Ahmad, a former group fighter, said he got $\$ 828$ from IRGC and $\$ 120$ from the Assad regime (Salaam Times, 2020 ). It can be contended that their average salary is $\$ 800$. This means that they earn 30 times more than they do in Afghanistan and three times more than in Iran when working as illegal workers. However, what attracts 
them more is a permanent residence or citizenship. Iran offers them and their families residence or citizenship if they join its proxies.

Nonetheless, some ex-militants confessed that Iranian authorities granted only temporary residences starting from as little as one month even though they went to Syria for a few rounds lasting at least three months. The Afghan interviewee Ahmad Abodin said that permanent residence is given only when migrants fight three times in Syria (A. Abodin, personal communication, November 12, 2020). However, it should be noted that some of them accepted fighting voluntarily as well. While some volunteer fighters went to Syria for religious reasons, some others accepted the offer to make money (HRW, 2016).

Also, some ex-fighters said that they were forced to go to Syria repetitively, but they escaped Iran and took refuge in other countries. As per their statements and interviews, they made with Western media; their leading destination seems to be Europe via Turkey. Moreover, many interviewees confessed that when they were asked to join Liwa Fatemiyoun for another round, they put forward excuses such as visiting their families and going to Mashhad city for pilgrimage and then crossed the Turkish border and arrived in Greece (Hamidi, 2019). However, not all fighter refugees stepped on the Greek islands. Turkish authorities estimate that there are approximately one million registered and unregistered Afghans in Turkey. Since former Liwa Fatemiyoun members use Turkey as a crossroad to Europe, some of them are likely in Turkish cities. However, Sohaib Abdollahi, who was interviewed for this study, has few former group fighters among fighters. He argues that "Those coming to Turkey and heading to Europe are actually Sunni youth having links with radical groups. Iran allowed them to cross the border to create chaos in destination countries (S. Abdollahi, personal communication, October 17, 2020)". Even if Abdollahi's views are correct, some Afghan migrants escaped from Afghanistan to Iran for better living conditions but found themselves clashing in somebody else's war. When they understood that they had escaped from the bad (Afghanistan) to the worse (Iran) and sometimes to the worst (Syria), they fled to Turkey and European countries.

Regarding Iran's end for wielding Afghan immigrants as combatants, first, like all principals, it minimizes its losses by using recruiting Afghans to its proxy Liwa Fatemiyoun. Iran actually relied on IRGC in Syria, but when 
the number of casualties rose to an unbearable level, they first invited Hezbollah and then brought other Shiite proxies. The more it lost to the Syrian opposition, the more it brought foreign fighters to Syria. Had IRGC been successful in Syria, it would probably not call for militants and not separate and rename Afghan fighters as Liwa Fatemiyoun. Therefore, its failure led to the formation of the group. Second, besides lessening casualties of Republican Guards, the Iranian regime tries to show its population that Iranians and all other people with Shiite faith are in Syria for defending Islam. It also gives Afghans the message that their sons fought for a holy cause by the same token. Therefore, they glorify killed militants through naming streets after them, top-level IRGC attending funerals and parading and burying their coffins in high-status cemeteries (Hamidi, 2019; Saheb Khaber, 2016; Hayat, 2016; Isaar, 2016; Modafeon, 2017). Besides top officials, even Iran's spiritual leader Ayatollah Ali Khamenei praised them and said 'I am proud of you' during a funeral ceremony held in March 2016 (Peterson, 2016).

A third reason is that the Iranian army is claimed to use Liwa Fatemiyoun members as cannon fodders in the war. Those fighting for the group revealed various durations of military training ranging from fifteen days to three months. Nevertheless, it seems that their training was far from being efficient as their losses were very high. However, in any case, Iran trained 50.000 Afghans recruited from illegal immigrants and refugees. Morally and as per international law, displaced people should be embraced, and their basic needs must be met. Nevertheless, in Iran, Afghans were transformed into fighters and eventually they became either lethal militants or refugees heading to other countries. Iran's policy is unique even among its other proxies because Shiite Afghans, namely Liwa Fatemiyoun, are more mobile than any other proxies. For example, Hezbollah members might be expected to return to Lebanon, Iraqis to Iraq, and Pakistanis to Pakistan, but Afghans are mainly mobile. This does not mean that Afghans can not repatriate to their home country. It is possible, and some of them have already returned to Afghanistan, but unstable political conditions and sectarian conflicts make their hometowns hardly attractive. Yet, if the Iranian regime decides to intervene in Afghanistan directly or indirectly, fighters' choices will probably be ignored.

From a theoretical perspective, I contend from this section that Iran's human source of Liwa Fatemiyoun is not freedom fighters of an ethnic 
group but refugees escaping from their countries. Typically, a principal finds an already formed and ready proxy and invests in them. In our case, Iran forms it from disadvantaged people and trains them for fighting. Besides, the facts in this section strengthen the theory that Iran gives afterdeath promises to proxies. Afghan militants are not expecting the freedom of their lands when the war is won, nor they await privileges stemming from victory as all earnings go to Iran. Therefore, Liwa Fatemiyoun as a proxy has no mutual benefit in its engagement with the principal, Iran. In association with this theory, the above facts strengthen the other theory that Iranian proxies are operating like paramilitary groups since they fight for some fiscal benefits and some residential advantages while being in Iran as refugees. However, it must be added that their families are given citizenship after their deaths (Shirmohammadi, 2016). While it is not a benefit for the deceased, it is undoubtedly an excellent favor to his family. However, it does not change the fact that death is exchanged with citizenship.

\section{Is Liwa Fatemiyoun a Threat to Afghanistan?}

The United States and Taliban signed a peace deal on February 29, 2020, which stipulates the withdrawal of US troops from Afghanistan within 14 months. In line with the deal, US officials announced on March 9, 2020, that they were making preparations to reduce its troops from 12.000 to 8.600 within 135 days from the agreement's signing date. While the deal raised concerns about the country's future, some analysts had fingered out the return of Afghan fighters and their utilization by the Iranian regime. One of those analysts is Phillip Smyth, who wrote for the Washington Institute in 2014 as; "As the United States begins its broader pullout from Afghanistan, Tehran could decide to reorient its new network of Afghan proxies eastward, to assert broader influence among Afghanistan's often fractious Shiite communities (Smyth, 2014)". On the other hand, the threat that the returned fighters posed to Afghanistan began to appear on media only from 2016 onwards. For example, Mashal and Faizi (2017) conducted some interviews with those who returned to Afghanistan for The New York Times. While one of the fighters said; "The Guards commanders were saying that, if it comes to it, we will make Bamian into a base for you, a base for Fatemiyoun", another one told reporters that; "There was always talk about that; the commander would say that one day you will go 
defend in your own country". Furthermore, Hamid, a former fighter told to news agency Voice of America (VOA) that some of Fatemiyoun fighters brainwashed by Iran would be equipped to fight in Afghanistan (Kajjo, 2019). What is more, Ismail Qaani, the deputy commander of Quds Force, said in a memorial day organized for deceased fighters that; "Fatemiyoun is a new culture - a collection of brave men who do not see boundaries and borders in defending Islamic values". It should be noted here that Qaani replaced his predecessor Qasem Soleimani after the US forces in Baghdad killed the latter on January 3, 2020.

The returning fighters struggle to reintegrate with society and feed their families, but many seem to have failed (Jamal, 2019, p. 1). They also live with the fear of likely crackdowns conducted by the Afghan government, Taliban or ISIS remnants. Returnees are young, unemployed, well-trained in military terms, and have connections with IRGC. Besides, objecting to IRGC officials' commands might lead to losing residence permits and other granted rights. Moreover, some Fatemiyoun fighters have a solid allegiance to the Iranian regime. They underline their readiness for new missions in many of their statements (Majidyar, 2017). While experts advise the Afghan government to help fighters reintegrate, they do not suggest how the government of a failed state will achieve it.

Moreover, the Associated Press reported that roughly 10.000 veterans of Liwa Fatemiyoun returned to Afghanistan (Gannon, 2019). This is a massive number for the Afghan government to control, follow up and rehabilitate since it is short of sources to realizing this goal. Besides, fighters are disorganized and probably more loyal to Shiite Iran than Sunni Afghan government. On the other hand, Gannon underlines that some Afghan politicians in the government already support Liwa Fatemiyoun members Some Afghan security officials assert that Iran may form a secret army from ex-fighters and mobilize them against the Afghan government, particularly after US withdrawal (Kajjo, 2019).

However, Zabihullah Salihi, an Afghan academician, thinks quite differently about the danger Liwa Fatemiyoun might pose Afghanistan. He said in the interview exclusive to this study that "Iran's strategic allies are not Hazaras but Tadjiks. Iran did not invest much on Hazaras. What is more, thousands of Hazaras were killed by Sunnis with weapons supplied by Iran in 1992 (Salihi, personal communication, December 25, 2020). He adds 
that "The chaos is created mainly by Sunni groups. Last week (November 9-15, 2020), 24 Hazara teenagers participating in an education course were killed by a bomb attack. The attackers were Sunni groups. Before Iran, there are other countries like Pakistan, the UAE and Saudi Arabia that intervene in domestic politics of Afghanistan". Nevertheless, Iran's Foreign Minister Jawad Zarif called Liwa Fatemiyoun fighters to return to Afghanistan to fight alongside the Afghan government in December 2020 (Independent Persian, 2020). An open and official call from the top Iranian diplomat should be satisfactory enough that Iran will not hesitate to use the group in Afghanistan. Thus, it can be concluded that in case Iran directly or indirectly gets involved, it may use the group. On the other hand, claiming that Iran will spark a new civil or sectarian war in Afghanistan does not seem realistic.

Based on the above arguments, several arguments can be suggested. First, when Saddam Hussain was overthrown by the US in 2003, one of the most influential countries in Iraq became Iran to the Shiite majority in the country. Also, when US troops withdrew from Iraq in 2011, it became more effective for a while, but as of 2020, Iran is still the biggest co-actor in Iraqi politics. As always, Iran's strategy of manipulating the politics of other countries where the Shiite population has a considerable number is proxies. This is the case for Iraq as well. Iranian proxies in Iraq have even become a part of the Iraqi army. In Lebanon, Hezbollah is a big actor in country politics. Yemen and Syria are also under the influence of Iran via proxies. Why not Afghanistan with $20 \%$ of the Shiite population then? Second, Afghanistan has a fertile ground for Iran to grow Liwa Fatemiyoun since almost half of Afghan Shiites live in Iran. It is correct that Iran allies with even non-Muslim states like Armenia against Shiite Azerbaijan, but given that it has good relations with Afghan Shiites, it may wield them during a likely conflict. However, as Salihi said, Iran's relations with other Afghan groups must be spotted before its impact on Hazaras.

Third, if Iran decides to use ex-fighters returning to Afghanistan, they can easily be organized by IRGC, thanks to their connections with the latter. Besides, they can not oppose Iranian security officials since some fighters are residing in Iran. Fourth, since poverty-stricken and uneducated militants are prone to getting involved in the robbery and other crimes, a fair salary will easily attract them to join the proxy group ranks. Fifth, 
past experiences have shown that Taliban and other Sunni armed groups are less likely to live in peace with Shiites. If they persecute Shiites, Iran may intervene through its proxy in Yemen, Syria, Iraq, and Lebanon. Sixth, the withdrawal of US troops will facilitate Iran's intervention via Liwa Fatemiyoun. The US will not probably send weapons to Sunni groups to fight against Iran's proxy; thereby Iran will easily handle the case. From a theoretical perspective, Liwa Fatemiyoun in Afghanistan will make it an accurate proxy rather than a PMC, which is the case now. As argued above, while the group was fighting in other countries, it got some monetary benefits in return. However, the group will act as a simple proxy when it fights for its lands.

\section{Conclusion}

Iran's strategy of using proxies seems to have risen to a new level. Besides recruiting pious Shiites and paid militants, it also benefits immigrants who had to leave their countries due to war. Liwa Fatemiyoun group is one of these groups and the biggest Afghan proxy that IRGC founded through threatening Shiite Afghan migrants currently living in Iran. By this strategy, this study argues that the Iranian regime terrorizes victims of the war and worsens their lives for its foreign policy goals. What is more, Iran's strategy has the risk of being inspired by other states and non-state actors. Besides, it turns migration into a matter of security. Therefore, migrants might no longer be seen as displaced people struggling to survive but also potential militants. As mentioned above, some militants of Liwa Fatemiyoun already fled to Europe, and there is no guarantee that they will not get involved in any crimes. Besides the migrant aspect of Liwa Fatemiyoun, the group's being a pure Shiite Afghan organization causes worries about its future. More scholars and analysts now argue that Iran might gather ex-fighters in Afghanistan and threaten the country's fragile peace and security after US troops leave. Such a scenario is possible because even top Iranian officials disclose that Liwa Fatemiyoun might be used in Afghanistan. Finally, by elucidating Liwa Fatemiyoun, this research suggests more studies about migrant-based proxy structures, mobilization of proxies, and particularly the formation and transformation of surrogate groups. 


\section{Beyan}

$\mathrm{Bu}$ makale etik kurul kararından muaftır. Çalışmada katılımcı bulunmamaktadır. Çalışma için herhangi bir kurum veya projeden mali destek alınmamıştır. Çalışmada kişiler ve kurumlar arası çıkar çatışması bulunmamaktadır. Telif hakkına sebep olacak bir materyal kullanılmamıştır.

\section{Disclosure}

The article is exempt from the Ethics Committe Decision. There are no participants. The author received no financial support from any institution and there's no conflict of interest. No material subject to copyright is included. 


\section{References}

Al-Dassouky, A., Şaban, N., Abu Hashem, A., Tallaa, M., \& Majani A. (2019). The Syrian military establishment in 2019: Sectarianism, militias, and foreign investment. Omran Studies. https://omranstudies. org/publications/books/the-syrian-military-establishment-in-2019sectarianism,-militias-and-foreign-investment.html

Alijani, E., \& Hilliar, A. (2014, June 4). Afghan migrants offered $\$ 500$ by Iran to fight for Syrian regime. France 24. https://observers.france24. com/en/20140604-afghan-migrants-offered-500-iran-fight-pro-assadmercenaries

Bar-Siman-Tow, Y. (1984). The strategy of war by proxy. Cooperation and Conflict, 19(4), 263-273. https://www.jstor.org/stable/45083584

Byman, D. (2018, August 26). Why states are turning to proxy war. Los Angeles Times. https://nationalinterest.org/feature/why-states-areturning-proxy-war-29677

Deutsch, K. (1964). External involvement in internal wars. In Harry Eckstein (Ed.). Internal war: Problems and approaches. Free Press of Glencoe.

Ekşi, M. (2017). The Syrian crisis as a proxy war and the return of the realist great power politics. Uluslararası Kriz ve Siyaset Araştırmaları Dergisi, 1(2), 106-129, https://dergipark.org.tr/tr/download/articlefile/391797

Fox, A. C. (2019). In pursuit of a general theory of proxy warfare. Institute of Land Warfare Publication.

Gannon, K. (2019, April 1). Afghans recruited to fight in Syrian war struggle back home. AP News. https://apnews.com/9dadee87709e4c6 0ba8f7afe1caec $81 \mathrm{~b}$

Hamidi, M. (2019, July 8). The two faces of the Fatemiyun (I): Revisiting the male fighters. Afghanistan Analysts. https://www.afghanistananalysts.org/en/reports/regional-relations/the-two-faces-of-thefatemiyun-i-revisiting-the-male-fighters/

Hayat (2020). Bergüzari çehlemin ruz şehadet serdar müdafi haram "seyyiz hahim" der meşhed mukaddes. http://hayat.ir/125-3-128192

Human Rights Watch. (2016, January 29). Iran sending thousands of 
Afghans to fight in Syria. https://www.hrw.org/news/2016/01/29/iransending-thousands-afghans-fight-syria.

Independent Persian. (2020, December 19). Tevsiye Zarif be Kabil beray istifade ez leşker Fatimiyun der Afğanistan. https://bit.ly/2Pxl4lj

Isaar. (2016, May 16). Ceşen tevlid ferzendan erdibhaşti şühedayi Fatimiyon. https://bit.ly/3rRkFHv

Jamal, A. S. (2019). The Fatemiyoun army: Reintegration into Afghan society. United States Institute for Peace. https://www.usip.org/sites/ default/files/2019-03/sr_443-the_fatemiyoun_army_reintegration_ into_afghan_society-pdf_0.pdf

Jones, S. G. (2019, March 11). War by Proxy: Iran's growing footprint in the Middle East. CSIS Briefs. https://csis-website-prod.s3.amazonaws. com/s3fs public/publication/190312_IranProxyWar_FINAL.pdf

Kajjo, S. (2018, April 8). Returning from Syria, Iranian-backed Afghan fighters could pose threat. VOA News. https://www.voanews.com/ extremism-watch/returning-syria-iranian-backed-afghan-fighterscould-pose-threat

Krieg, A. (2016). Externalizing the burden of war: The Obama Doctrine and US foreign policy in the Middle East. International Affairs, 92(1), 97-113, https://doi.org/10.1111/1468-2346.12506

Latifi, A. M. (2017, June 30). How Iran recruited Afghan refugees to fight Assad's war. The New York Times. https://www.nytimes. com/2017/06/30/opinion/sunday/iran-afghanistan-refugees-assadsyria.html

Majidyar, A. (2017, January 18). Iran recruits and trains large numbers of Afghan and Pakistani Shiites. Middle East Institute. https://www.mei. edu/publications/iran-recruits-and-trains-large-numbers-afghan-andpakistani-shiites

Mashal, M. \& Faizi, F. (2017, November 11). Iran sent them to Syria. Now Afghan fighters are a worry at home. The New York Times. https:// www.nytimes.com/2017/11/11/world/asia/afghanistan-iran-syriarevolutionary-guards.html. 
Middle East Eye (2018, January 6). More than 2,000 Afghans killed in Syria fighting for Bashar al-Assad: Official. https://www.middleeasteye. net/news/more-2000-afghans-killed-syria-fighting-bashar-al-assadofficial.

Modafeon (2017). Teşyii peyker se şehid müdafi harem der meshed mukaddes. https://bit.ly/3ul2wmX

Mumford,A.(2013).Proxywarfareandthefutureofconflict.TheRUSIJournal, 158(2), 40-46, https://doi.org/10.1080/03071847.2020.1736437

Peterson, S. (2016, June 12). Iran steps up recruitment of Shiite mercenaries for Syrian war. CS Monitor. https://www.csmonitor.com/ World/Middle-East/2016/0612/Iran-steps-up-recruitment-of-Shiitemercenaries-for-Syrian-war

Pfaff, A. \& Granfield, P. (2018, March 27). How (not) to fight proxy wars. National Interest. https://nationalinterest.org/feature/how-not-fightproxy-wars-25102

Saheb Khabar (2020). Şekva veda' şehida Fat,miyon der zaviya durbinha. https://bit.ly/2PxWwIW

Sahraei, F. (2016, April 15). Syria war: The Afghans sent by Iran to fight for Assad. $B B C$. https://www.bbc.com/news/world-middleeast-36035095.

Salaam Times (2020, April 14). Yek makam Irani rivayet Tehran der mord 'davtalban' leşker Fatimiyon ranahi kırd. https://afghanistan.asia-news. com/prs/articles/cnmi_st/features/2020/04/14/feature-01

Shay, S. (2019, June 10). The threat of the new Shiite "Afghan alumni". RIEAS. http://www.rieas.gr/images/editorial/shauljune19x.pdf

Shirmohammadi, T. (2016, May 5). Itayi tabiyet İran be mehaciran Afğan be behay "şehid şenden". Deutsch Welle Persian. https://bit.ly/3fCEEax

Smyth, P. (2014, June 3). Iran's Afghan Shiite fighters in Syria. The Washington Institute. https://www.washingtoninstitute.org/policyanalysis/view/irans-afghan-shiite-fighters-in-syria

Therme, C. (2017). The Shi'a Afghan community: Between transnational links and internal hurdles. Iranian Studies, 50(4), 511-521, https://doi. org/10.1080/00210862.2017.1295537 
Uskowi, N. (2019). Temperature rising: Iran's revolutionary guards and wars in the Middle East. Rowman and Littlefield.

Washington Institute (2018). Direct Iranian proxies and their front groups involved in Syria. https:/www.washingtoninstitute.org/uploads/ Documents/pubs/PF138Appendices/PF138_Appendix_4-1.pdf

Worcester, M. (2014, August). Putin's proxy warfare strategy. ISPSW Strategy Series, (Report no. 284), https://www.files.ethz.ch/ isn/182503/282_Worcester.pdf 